\title{
Suitability analysis of China's energy development strategy in the context of water resource management
}

\author{
Yizi Shang a, *, Jianhua Wang a, Jiahong Liu a , Dong Jiang ', Jiaqi Zhai a, Shan Jiang a \\ a State Key Laboratory of Simulation and Regulation of Water Cycles in River Basins, China Institute of Water Resources and Hydropower Research, Beijing \\ 100038, China \\ b State Key Lab of Resources and Environmental Information Systems, Institute of Geographical Sciences and Natural Resources Research, Chinese Academy \\ of Sciences, Beijing 100101, China
}

\section{A R T I C L E I N F O}

\section{Article history:}

Received 5 October 2015

Received in revised form

17 December 2015

Accepted 18 December 2015

Available online 12 January 2016

\section{Keywords:}

Coal-fired power

Water demand for energy

Water-limited development

Energy-water synergy

Conciliation of conflicting policies

\begin{abstract}
A B S T R A C T
Coal is China's most important primary energy source, and is supporting the rapid economic growth going on there. However, the reverse geographical distribution of coal production and consumption results in a high cost of coal transportation and low efficiency of coal utilization. To ease the pressure on coal transportation, and to mitigate pollution in eastern coastal regions, China has kicked off a strategic west-east transfer of energy industries that requires the movement of coal power projects to the arid northwest regions. Under this strategic framework, the regulation is focused on "clean production", "consumption reduction" and "reuse", rather than conservation and protection of water resources. This study found that the northwest areas are unable to accommodate fully the planned scale of coal-fired power industry. Moreover, the subsidiary chemical industry, even if the scale of electric power development is determined according to the need for coal production, is problematic because the current water demand for the coal industry has exceeded "allowed water withdrawal". Given limited water saving potential and the huge demand-and-supply gap, it is also unrealistic to balance water demand by combination of water conservation in the power industry and water right diversion from agriculture. This study on the synergies between energy and water is urgently needed, in order to provide scientific and technological support for laying out new energy industries. A critical change should involve conciliation of conflicting policies or plans before implementation begins.
\end{abstract}

๑) 2016 Published by Elsevier Ltd.

\section{Introduction}

As the engine of rapid economic growth, China's coal consumption expanded by $135 \%$ in the last decade. In 2013, coal consumption hit 3.61 billion tons, accounting for over $50 \%$ of the world's total, and the number is expected to grow, reaching 4.8-5.3 billion in 2020 [1]. In 2013, coal took up 67.5\% of China's energy consumption structure, a slight decrease from the previous year. However, the current great dependence on coal will not change in the next ten years, judging from resource endowments (up to $94 \%$ of identified fossil energy reserves is coal), and current and future technological development [2]. Currently, $51 \%$ of coal is used for power generation and $29 \%$ for industrial fuels, a stable proportion in recent years [3].

\footnotetext{
* Corresponding author

E-mail addresses: yzshang@foxmail.com (Y. Shang),wjh@iwhr.com (J. Wang).
}

China's energy development strategy is to meet surging energy demand by increasing supply from the main producing areas. According to the Energy Development Strategy Action Plan (2014-2020) (hereinafter referred to as the "Action Plan") released by the State Council in September 2014, China will build nine $10 \mathrm{GW}$ (gigawatt) coal-power bases in Shanxi, Shaanxi, Inner Mongolia, Ningxia, and Xinjiang; more specifically in Xilin Gol, Erdos, Northern Shanxi, Middle Shanxi, Eastern Shanxi, Northern Shannxi, Kumul, Zhundong, and Eastern Ningxia (Fig. 1). However, these regions are arid or semi-arid and mainly rely on natural precipitation that is typically less than $400 \mathrm{~mm}$ annually, with a maximum of $600 \mathrm{~mm}$ in good years [4]. In addition, evaporation is greater than precipitation in certain areas in Xinjiang and Ningxia.

In view of the relative water and energy shortages, China has attached high importance to energy and water conservation. However, it is only after implementation of the "most stringent water resources management system" that the carrying capacity of water resources is considered an important condition for regional 


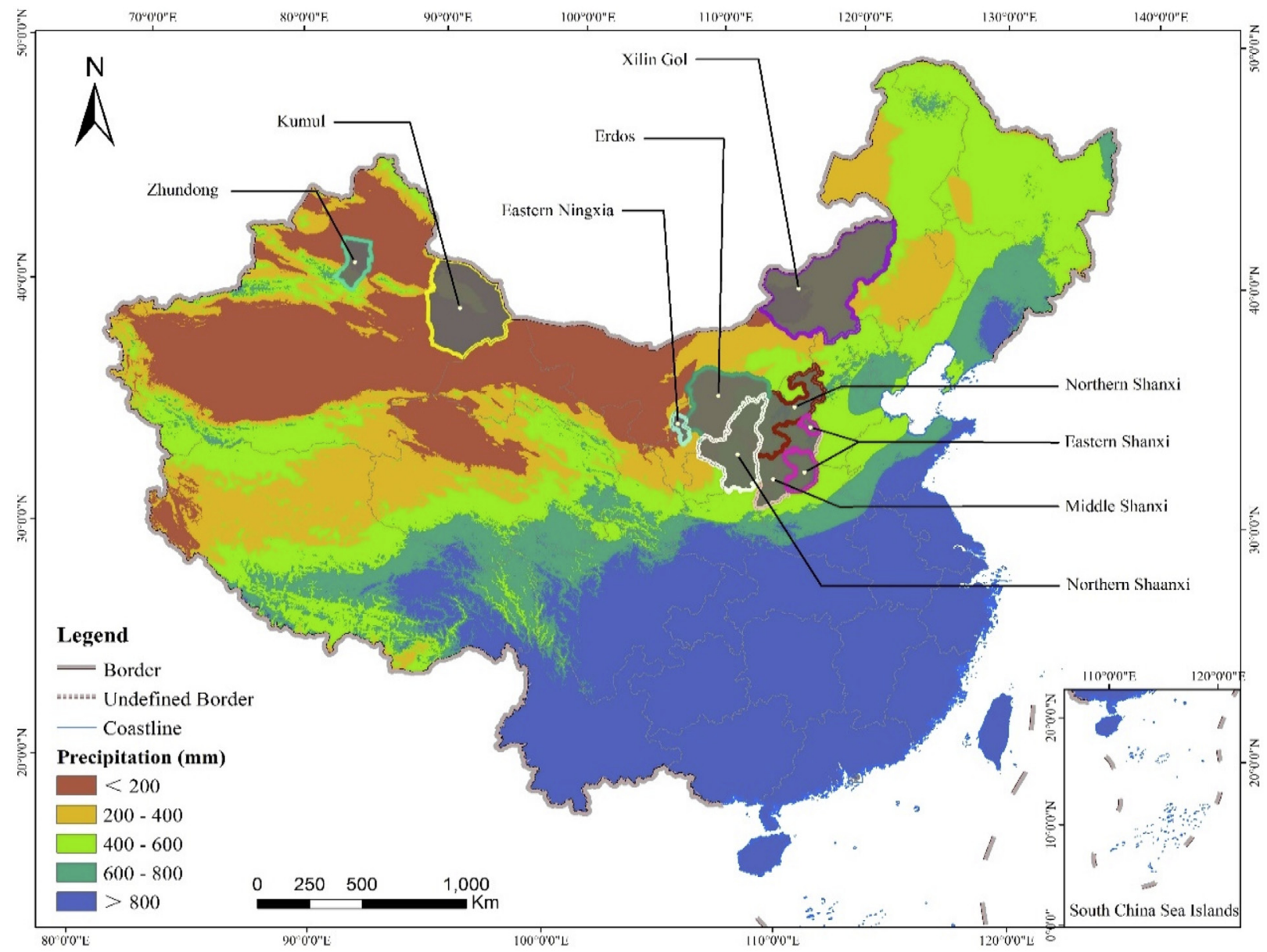

Fig. 1. Distribution of planned coal power bases in China and average annual precipitation (Source: Author's mapping).

development and industrial layout. Previously, energy development strategies were focused on "clean production", "consumption reduction" and "reuse" and did not set targets for water conservation and protection [5]. The relationship between water resources and the energy system is very complex. Energy conservation and water conservation are not simply identical and not always consistent. In some cases, energy conservation can produce water savings, but in some cases, entails more water consumption [6]. In this grave water and energy situation, an indepth study of water and energy synergies is of particular importance for the healthy development of both water and energy resources.

This paper firstly introduces China's West-East Power Transmission Project and "the most stringent water resources management system", then analyzes water resources constraint on national coal industry development, and finally identifies the major constraints on the coal-fired power industry within energy bases areas from the perspective of coal production capacity and water resources management. It also puts forward policy recommendations for comprehensive water and energy management. This paper is structured as follows: Section 2 briefs for China's strategic imperatives to develop major coal power bases in its dry northwest region. Section 3 introduces the water resources constraints on coal power development on national and coal power base scale respectively; Sub-section 3.1 gave an overview of water resources conditions for the planned coal power bases; Sub-section 3.2 analyzed synergies between water needs of future national coal industry development and its total water consumption control, and
Sub-section 3.3 roughly estimates coal power development scale for coal power bases under the constraints of coal production and water use. Section 4 concluded this paper.

\section{China's West-East Power Transmission Project}

West-East power transmission is a compelling move. The current coal-dominated energy structure will face a number of challenges of many aspects, including natural conditions, regional economic and social development, and environmental pressure. Coal is mainly stored in the western and northern regions, but used in economically developed eastern and central regions, and relatively developed southern regions. The reserve distribution of coal producing and consuming areas results in high cost of transportation and low efficiency of use [7]. It is estimated that coal transportation is uneconomic if the distance between coal mine and power plant is over $1000 \mathrm{~km}$ [8]. Currently, coal transportation takes up more than $50 \%$ of the national total rail capacity and puts extreme pressure on road traffic [9]. China is vigorously building out its railway network including the Trans-Mongolian Railway and other channels, which to some extent, are expected to ease transportation pressure. Nevertheless, there is no fundamental change expected in the situation of heavy reliance on coal transportation and high costs of long-distance transportation [10].

In addition, serious air pollution has been caused in major cities in eastern and central regions along with coal transmission [11]. At present, the eastern and central regions have an installed thermal power capacity of $540 \mathrm{GW}$, accounting for $66 \%$ of the national total. 
The installed capacity in urban groups in the Bohai Economic Rim reaches $130 \mathrm{GW}$, and the installed capacity per unit of area is 13 times that of the northwest areas. The numbers read 140 and 26, respectively, in the more developed Yangtze River Delta. To put it more vividly, there is a power plant every $30 \mathrm{~km}$ on average along the Yangtze River, and every $10 \mathrm{~km}$ in the Nanjing-Zhenjiang section. Large-scale coal transportation from northwest to east, and coal-fired power generation, has caused serious air pollution in eastern and central regions. All of the 104 national heavy-acid-rain areas are located in eastern and central regions; the $\mathrm{SO}_{2}$ emissions per unit of area in the eastern region are 5.2 times the level of the western region. In 2013, the Chinese Government identified air pollution as one of the most important aspects of environmental protection, and launched a medium and a long-term plan to address air pollution in the Beijing-Tianjin-Hebei region. The coal industry is forced by "pollution prevention and control" to transform and upgrade [12].

China has launched a coal and power integration program in the coal bases to provide long-distance power supplies to economically developed eastern and central areas, and this is accompanied with phase out a number of coal power plants in those areas. Featuring construction of power and chemical plants near coal mines, this strategic initiative promotes a revolution in energy production and consumption and boosts economic restructuring [13]. The cost of coal transportation is eliminated for power and chemical plants, and besides the costs of operating coal mines, coal chemical and coal power plants are also minimized because the coal mines and coal chemical plants can directly use power from the power plants. Meanwhile, the power plants can also use low-quality coal, including coal slurry and waste roc, for power generation, avoiding the waste of energy resources of low calorific value, and indirectly improving energy efficiency. More importantly, the West-East Power Transmission Project will effectively mitigate air pollution, particularly fog and haze, in major cities in the eastern and central regions.

\section{Constraints on coal industry development}

\subsection{China's water resources management context}

Since the reform and opening up, China has maintained an annual GDP increase of about 10\% during 1978-2012 [14], but the extensive, fast economic growth driven by production expansion entailed massive water consumption [15]. In some areas, groundwater was used as a complement to surface water to support the local economy and over-exploitation resulted in a sharp decline in the groundwater level, causing a series of after-effects [16]. These include such as a large-scale underground sinkholes in North China and desertification in the northwest arid areas. In addition, sewage has been directly discharged without treatment into rivers, causing surface water pollution that further exacerbates the shortage of available water [17]. In the expectation of an annual 7-8\% growth of the Chinese economy prior to 2020 [18], the national water consumption will continue to increase with the industrial scale, even though water efficiency has been significantly improved in the transition to an intensive mode of economic development (People.cn, An Average 0.9\% Annual Increase in National Water Consumption. Accessed March 2015, http://finance.people.com.cn/n/ 2015/0323/c1004-26731877.html) (Fig. 2).

China has a total water resources reserve of 2.8412 trillion $\mathrm{m}^{3}$, ranking fourth after Brazil, Russia and Canada, but the available surface water resources amount to only 752.4 billion $\mathrm{m}^{3}$, with the rest being either uncontrollable floodwater or base flow. China is the world's largest water consumer, and accounts for about $13 \%$ of the annual total. In 2013, the national water consumption reached

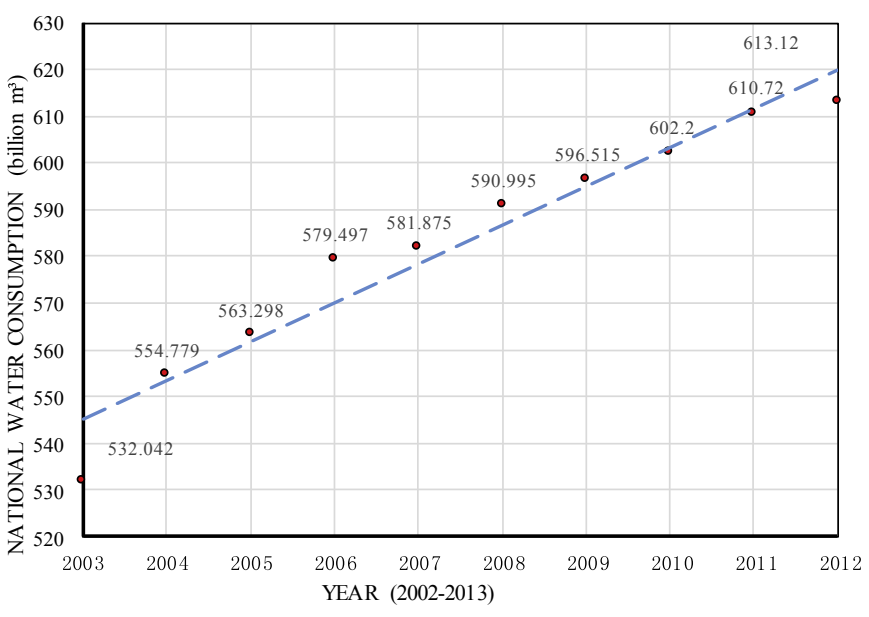

Fig. 2. National water consumption from 2002 to 2012 (Source: China Water Resource Bulletin 2003-2013).

618.3 billion $\mathrm{m}^{3}$, approaching the threshold of surface water resources needed for development and utilization.

The coal-rich regions are concentrated in the basins of Haihe River, Yellow River, and northwest rivers (Fig. 3) which have been 90\% utilized. In Haihe River Basin and Yellow River Basin, the actual water consumption has been $115 \%$ and $106 \%$ of the development and utilization thresholds of surface water resources, respectively [19]. To ensure the water supply for production and living, groundwater over-exploitation and water transfer are used separately or together, of which the former will result in underground sinkholes and land subsidence and the latter, adopted by executive order, may lead to "ecological transfer" and water disputes between basins [4].

To promote a rational industrial scale compatible with the carrying capacity of water resources, China put into effect the "most stringent water resources management system" in 2012 [20]. Taking into account the current level of water consumption and the future needs of socio-economic development and ecological restoration, the system sets out targets of total water consumption in the context of natural carrying capacity, of the water resources needed for industrial development. In 2020 and 2030, the national water use will be kept below 670 billion $\mathrm{m}^{3}$ and 700 billion $\mathrm{m}^{3}$ [19]. These targets have been broken down into administrative areas for mandatory implementation. To meet water demand beyond the allocation, industries have to carry out water saving transformation that improves the efficiency of water use or realize water reuse. Water quotas are an important indicator of China's micromanagement of water resources. According to the Water Law, the competent departments of provinces, autonomous regions and municipalities shall develop industry-specific water quotas for the administrative areas and obtain the approval of departments for water administration and for quality supervision and inspection for release by the governments. Water quotas shall be reported to the State Council departments for water administration and quality supervision and inspection for filing purpose.

From the perspective of planning and management, using water quotas, this paper explores the synergies and policy convergence between control of coal production and water consumption, and on this basis, identifies major constraints on the coal industry. Herein, water quotas are sourced from Water Quota for Major Industries announced by the governments of energy bases; "strict water quotas" refer to water-saving targets from Building a Water-saving Society announced by the governments. Water quotas are set taking into account water management capability improvement and water-saving technological advances. 


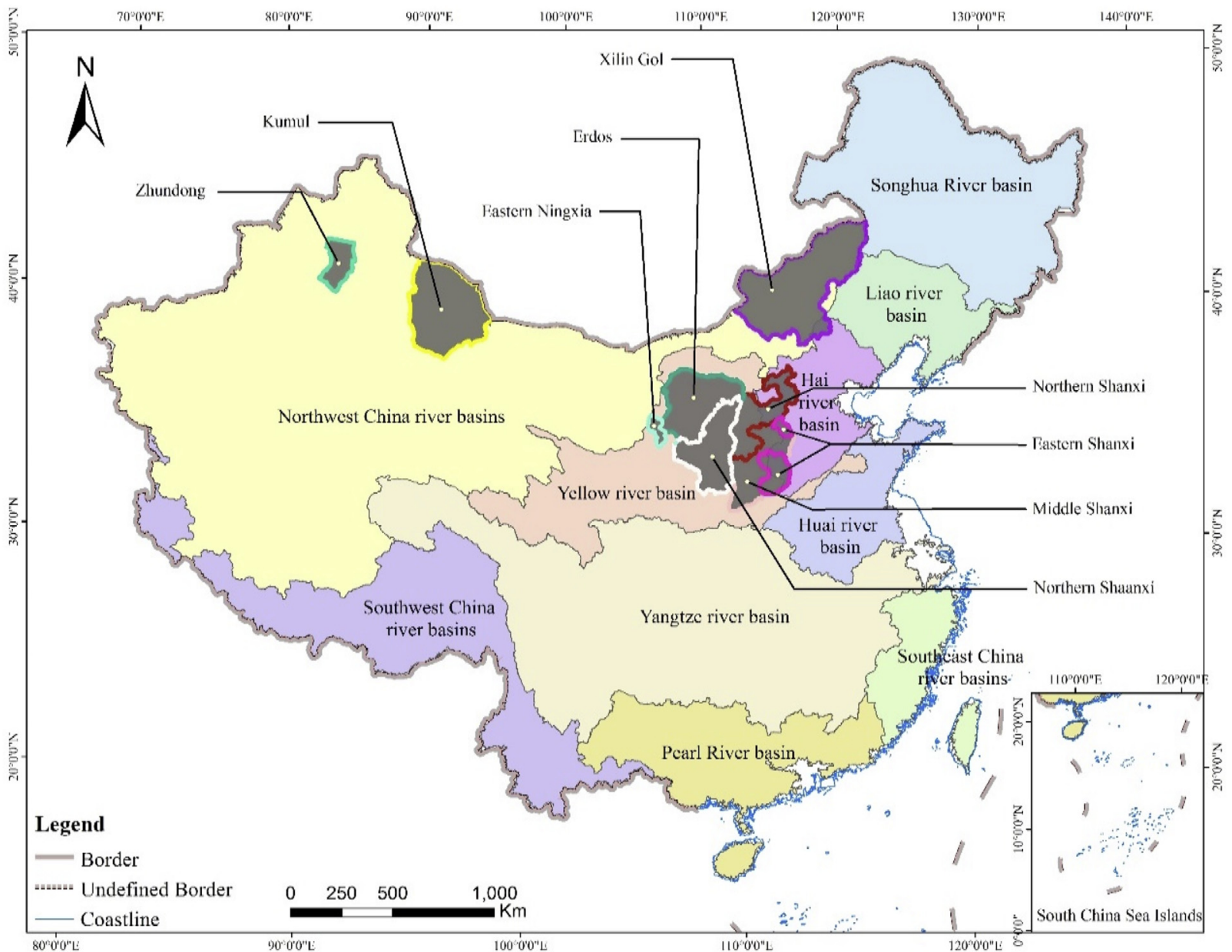

Fig. 3. Planned distribution of coal power bases in China by river basin (Source: Author's mapping).

3.2. Synergies between total water consumption control and coal industry development

\subsubsection{Scenarios}

China will implement an efficient, market-based policy that sets mandatory targets for total coal consumption control, to accelerate the "reduction" and "clean" process of coal consumption, according to the Action Plan. The national total coal consumption will continue to increase in the near future, but a peak and decline is expected as a result of energy restructuring and clean energy development [21]. Fig. 4 shows the changes in the BAU (Businessas-Usual) scenario and the TCC (Total-Coal-Consumption-Control) scenario set by NEA (National Energy Administration) [22]. In BAU, coal consumption will peak at 4.818 billion tons in 2030; and in TCC, at 4.063 billion tons in 2020, making a difference of 755 million tons, equivalent to $23.6 \%$ of the current total coal consumption.

Water conservation is the inevitable trend and the basic requirement of future economic and social development. It will exert a marked impact on the water use of national economic sectors. To measure the impact, this study establishes at conventional water-utilization mode and enhanced water-saving mode. In the former, the water use of different sectors in different scenarios is examined in accordance with the current levels of total water consumption and water quotas. The latter considers the application of water-saving technologies, strict water quotas when coal production expands, and phase-out of

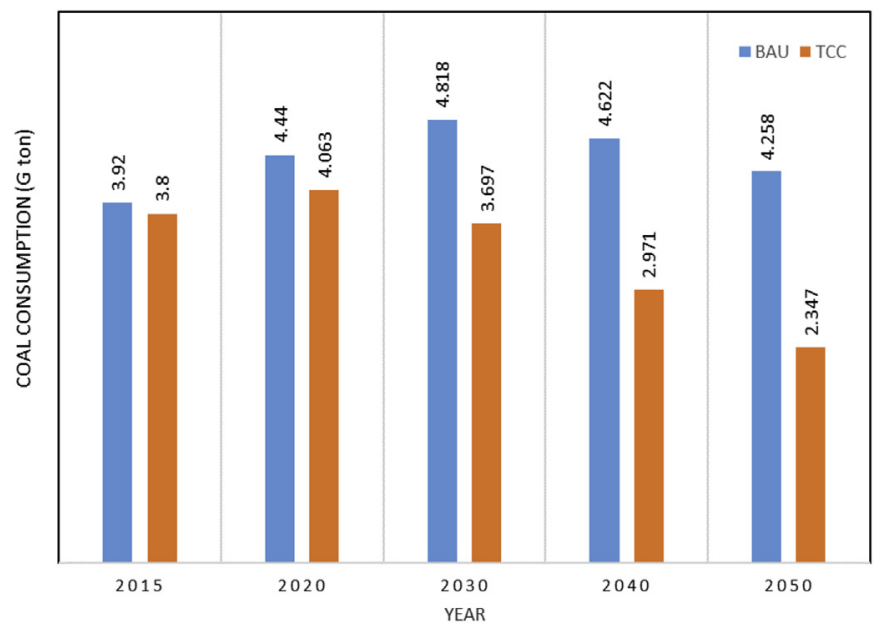

Fig. 4. National coal consumption scenarios

backward production capacity when coal consumption gradually declines, as well as the increase of overall water conservation. In this study, two approaches including four scenarios are considered, specifically the conventional water utilization approach (a. cBAU; b. cTCC) and the enhanced water saving approach (a. eBAU; b. eTCC). 


\subsubsection{Scenarios analysis}

This section analyzes the results for these four scenarios. As shown in Fig. 5, in cBAU (conventional water utilization approach), the water use of the coal industry will increase sharply and peak at 104.784 billion $\mathrm{m}^{3}$ in 2030 , an increase of $61.7 \%$ over the current level; while in CTCC, the peak is expected to arrive in 2020 (86.793 billion $\mathrm{m}^{3}$ ). Between the two scenarios, there is a difference of 17.991 billion $\mathrm{m}^{3}$, equivalent to $27.8 \%$ of the current total water consumption. In all years except 2050, the water consumption will surpass the RUW (restricted use of water by proclamation) in both scenarios, and the gap is as large as 38.682 billion $\mathrm{m}^{3}$ in the cBAU scenario.

In the enhanced water saving approach, the water consumption of the coal industry is expected to reach a peak of 81.953 billion $\mathrm{m}^{3}$ in 2030 in the eBAU scenario and 72.082 billion $\mathrm{m}^{3}$ in 2020 in the eTCC scenario, representing a decrease of 9.871 billion $\mathrm{m}^{3}$. As shown in Fig. 6, the RUW level is always surpassed in eBAU, and in eTCC, by 2.689 billion $\mathrm{m}^{3}$ in 2015 and 654 million $\mathrm{m}^{3}$ in 2020 .

As a whole, with the arrival of peak coal consumption, coalrelated industries are facing strong water constraints. Although the total water consumption can be drastically curtailed in the enhanced water saving approach, it is difficult to meet the red line requirement in the near future. From the perspective of integrated water resources management, the water consumption for the coal lifecycle has exceeded the red line. Industries now being planned need to scale down, even though western coal reserves are adequate to support "coal power" and its subsidiary industries.

\subsection{Maximum coal-fired capacity estimate for major coal power bases}

The State Grid Corporation of China has estimated the new installed capacity according to coal production capacity and analyzed the atmospheric impact of emissions from coal-fired power generation [23]. According to its report, emissions will increase with the installed capacity of coal-fired power generation, but if the new emissions control standards applied to old units are transformed at the same time, the total amount of emissions can be reduced. The report concluded that the West-East Power Transmission Project is feasible. In other words, the scale-up of installed power capacity in the northern and western areas will not entail a sharp increase of emissions. In 2014, the Study on Carrying Capacity

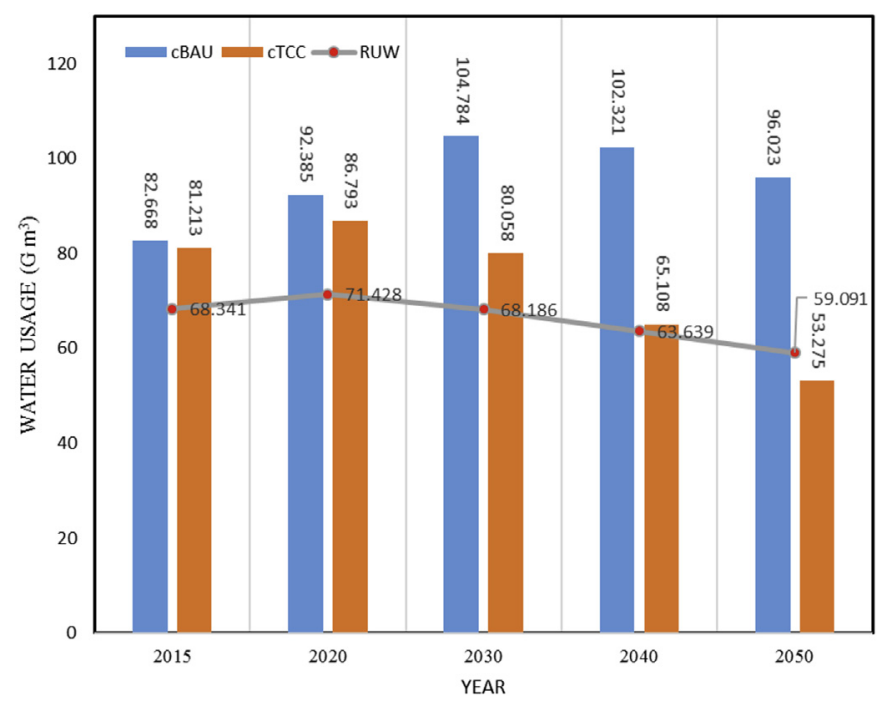

Fig. 5. Coal industrial water use in conventional water utilization approach.

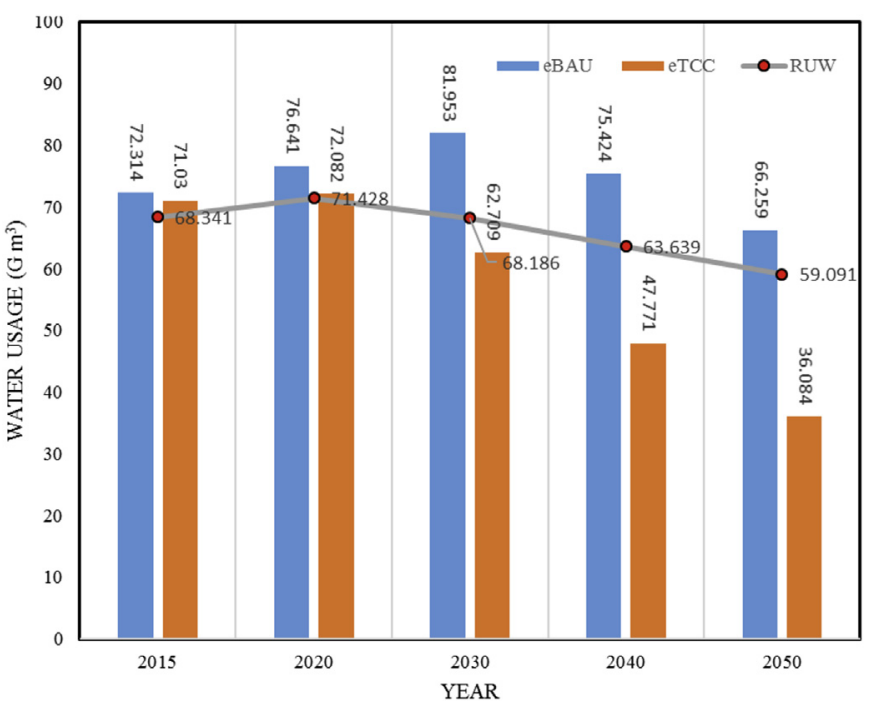

Fig. 6. Coal industrial water use in the enhanced water-saving approach.

of Water Resources at Energy Bases, carried out by the China IWHR (Institute of Water Resources and Hydropower Research), calculated the maximum installed capacity allowed by local water resources, which is considered a pre-condition for coal power development [22]. The steps are: 1) measuring the amount of available water resources at the coal power base; 2) determining the maximum incremental water supply according to water-usecontrol indicators and water supply capacity; and 3) estimating the installed capacity of coal-fired power generation that local water resources could support, using the quota method (the water indicator is $\mathrm{m}^{3} / \mathrm{s} \cdot \mathrm{GW}$ (the cubic meters of water used per second to produce $1 \mathrm{GW}$ (gigawatt) of electric power) [24]. The results of the two above-mentioned studies are as shown in Table 1.

It should be noted that the IWHR calculations focus on aircooled units (assuming that all new power plants use an efficient water-saving system). This means that the obtained figure of installed capacity is relatively large. Even so, as shown Table 1, the major constraint comes from water resources rather than coal production. In fact, China's coal sector has basically completed industrial upgrading and restructuring and applied the world's advanced technologies for water use control [25]. Water use efficiency is high and water has been mostly recycled. A number of power plants even have achieved zero discharge of wastewater. Fig. 7 shows the level of water consumption of coal power bases.

From 2001 to 2006, the installed capacity increased rapidly, driven by the strong demand for power that accompanied rapid economic development. This pushed up the water use for power generation. In later years, China adjusted the economic structure and took the path of intensive development. Water used for power generation was reduced during 2006-2008 by shutting down and deactivating a number of energy-intensive, water-consuming power plants. Power plants built after 2008 are required to apply a dry-cooling system to improve water use efficiency. However, the scale expansion of the power industry will still drive a slow increase in total water use. It is expected that water use for power generation will continue to increase in the future with China's economic recovery and growth in power demand (Xinhua Report, China's Economic Growth Stabilized, as Slowdown Almost Bottomed Out. Accessed Oct 2012, http://news.xinhuanet.com/ english/business/2012-10/22/c_131921930.htm). In 2015, the industrial chain for planned coal power bases will have a water demand of 9.975 billion $\mathrm{m}^{3}$, of which the coal mining industry 
Table 1

Installed capacity of coal-fired power generation within the constraints of coal production and water use.

\begin{tabular}{|c|c|c|c|c|c|c|}
\hline \multirow[t]{2}{*}{ Coal power base } & \multicolumn{3}{|l|}{$2020(\mathrm{GW})$} & \multicolumn{3}{|l|}{$2030(\mathrm{GW})$} \\
\hline & $\begin{array}{l}\text { Coal-supported } \\
\text { installed capacity }\end{array}$ & $\begin{array}{l}\text { Water-supported } \\
\text { installed capacity }\end{array}$ & $\begin{array}{l}\text { Maximum installed } \\
\text { capacity }\end{array}$ & $\begin{array}{l}\text { Coal-supported } \\
\text { installed capacity }\end{array}$ & $\begin{array}{l}\text { Water-supported } \\
\text { installed capacity }\end{array}$ & $\begin{array}{l}\text { Maximum installed } \\
\text { capacity }\end{array}$ \\
\hline Erdos & 91 & 90 & 90 & 148 & 138 & 138 \\
\hline Xilin Gol & 86 & 47 & 47 & 85 & 50.3 & 50.3 \\
\hline Eastern Ningxia & 80 & 75 & 75 & 150 & 137 & 137 \\
\hline $\begin{array}{cl}\text { Shanxi } & \text { Northern } \\
\text { Province } & \text { Shanxi } \\
& \text { Middle } \\
& \text { Shanxi } \\
& \text { Eastern } \\
& \text { Shanxi }\end{array}$ & 208 & 115 & 115 & 283 & 170.4 & 170.4 \\
\hline Northern Shaanxi & 99 & 74 & 74 & 150 & 100.8 & 100.8 \\
\hline Zhundong & 40 & 36 & 36 & 80 & 68 & 68 \\
\hline Kumul & 36 & 16 & 16 & 60 & 29 & 29 \\
\hline
\end{tabular}

accounts for $66.6 \%$, thermal power industry $22.2 \%$, and the coal chemical industry, $11.1 \%$ [26]. In addition, the large-scale development of coal power bases will consume at least 10 billion $\mathrm{m}^{3}$ water every year, more than $25 \%$ of the Yellow River water supply for a normal year.

Currently, agricultural irrigation accounts for $78 \%$ of total water consumption in coal power bases (Fig. 8), but in the face of tremendous pressure to ensure the domestic food supply, it is unlikely that much agricultural water will be re-directed to the coal and power industries [26]. China has set the goal of a $95 \%$ food-selfsufficiency rate and boasted over the years "supporting $22 \%$ of the world's population with only $7 \%$ of arable land". However, the arable land shrank by 800 million hectare in the past 12 years, while the total population grew stably at a low rate. To accomplish the national food security objective, the major grain producing areas consolidated the irrigation facilities and renovated the old irrigation systems while developing controlled environmental agriculture, and successfully improved the water efficiency of irrigation. IWHR forecasted that, if there is no significant change in planting structure and crop varieties, water consumption in the main grain producing areas will remain stable or even increase [27]. Even though the energy industry is given priority, water right redirection from irrigation will be quite limited because the premise is not to comprise "production in the main grain producing areas". Fig. 9 illustrates the location of coal power bases and grain producing areas.

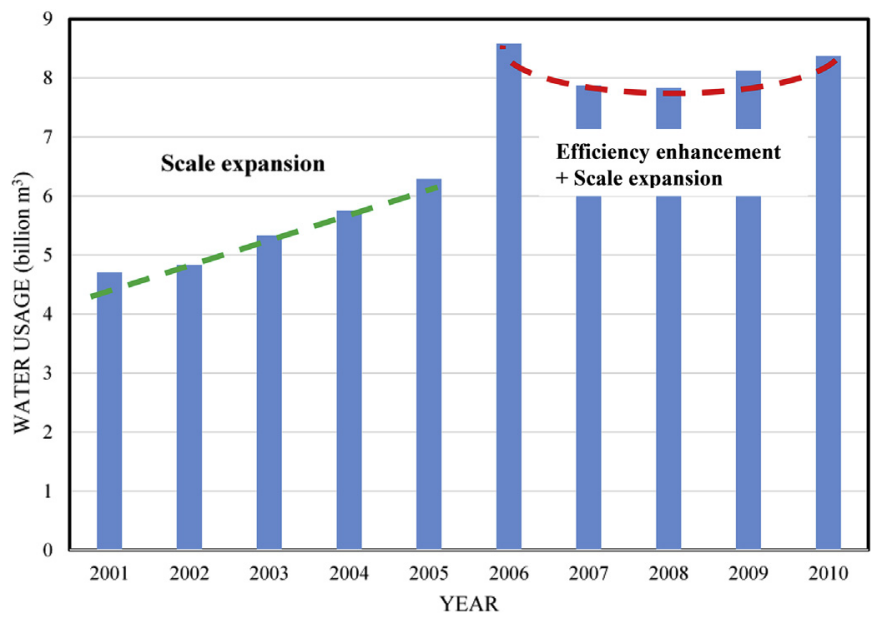

Fig. 7. Water use for power generation in China (Source: Literature [22]).

\section{Discussion and conclusions}

To ease the pressure of coal transportation and mitigate pollution in eastern coastal regions, China has to transfer coal power projects to northwest arid regions. These coal power bases are largely distributed in the upper and middle reaches of the Yellow River and basins of northwest inland rivers where water resources are scarce and $90-115 \%$ of available water resources have been used (close to or above the thresholds). Obviously, the arid northwest cannot accommodate all the planned coal power projects. It is unreasonable to determine the scale of coal power bases according to coal production because the water demand of coal industrial chain has exceeded the amount of "allowed water withdrawal". It is also unrealistic to expect water savings through technological transformation because the water efficiency is already high at the coal energy bases. In addition, most coal-fired power bases are located in the main grain-producing areas, and the competition for water use between the two leaves little room for water right diversion to support coal power development.

Already, impacts from water environmental and ecological issues have become apparent in the northwest energy bases, such as decreased compliance in water functional zones, groundwater overexploitation, and loss of biodiversity. The large-scale construction of coal power bases will exacerbate the emerging water crisis in the western provinces. More critically, the authority for water and energy management fall into different departments, including MWR and NEA, which results in a separate rather than integrated approach in water and energy management. Having independent development plans formulated by these departments, without a process of conciliation, causes considerable

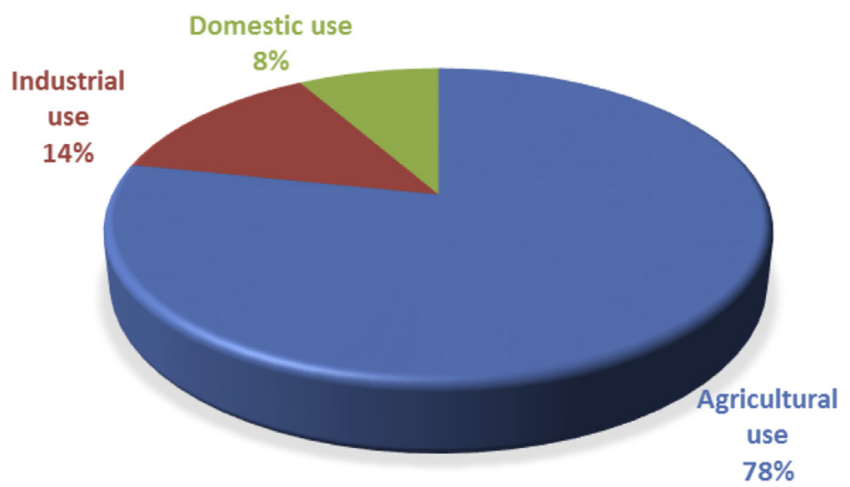

Fig. 8. Sector-specific water use of planned coal power bases in 2013 (Source: China Water Resources Bulletin). 


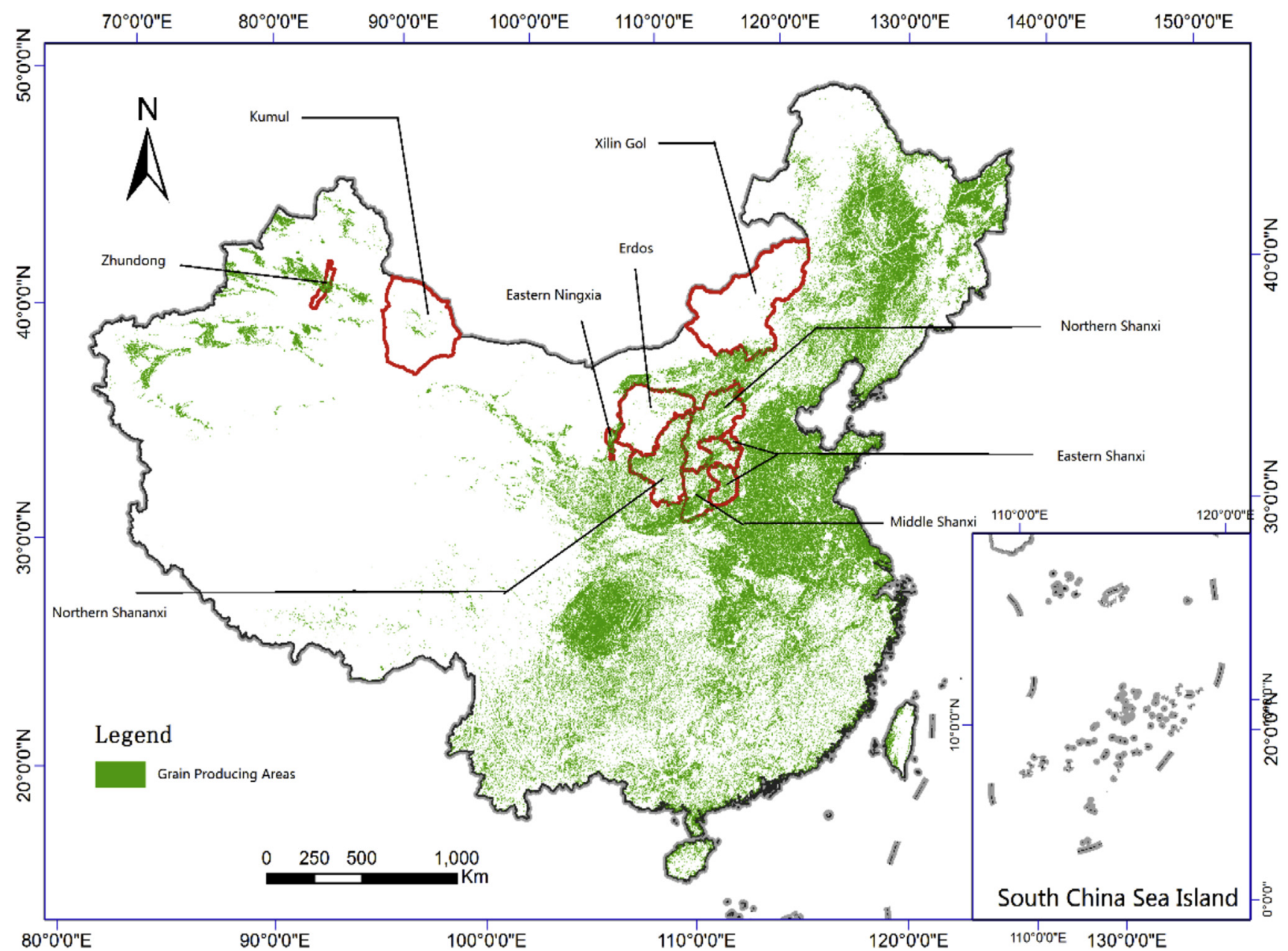

Fig. 9. Distribution of coal power bases and grain producing areas (Source: Author's mapping).

inconvenience to collaborative promotion of water and energy security.

In 2014, the World Bank launched "Thirsty Energy"program to assess the impact of water shortage on energy development and utilization from a global perspective. IWHR took the lead in the initiative through joint research with Tsinghua University on the "Effects of Water Constraint on Energy Development and Utilization", providing a case study in China. This study, as a component of that research, is intended to raise awareness about water constraints and to provide scientific and technological support for NEA in the formulation of the 13th Five-Year Plan for energy development.

\section{Acknowledgement}

This work was supported by the National Natural Science Foundation of China (Grand nos. 51579248, 51109112, 51522907, 51309249), and the Open Research fund of State Key Laboratory of Hydroscience and Engineering (Grand no. 2015-B-03), State Key Lab of Water Resources and Hydropower Engineering Science (Grand no. 2014SWG03), State Key Laboratory of Simulation and Regulation of Water Cycle in River Basin (Grant no: IWHR-SKL201517), and CRSRI (Grant no. CKWV2014224/KY). Furthermore, Special fund from China Institute of Water Resources and Hydropower Research is acknowledged for partial financial Support (Contract No: WR0145B02201500000).

\section{References}

[1] China National Coal Association. China coal research institute. Annual report on coal industry public companies (2013) [R], Beijing. China: Economic Press 2013 [in Chinese].

[2] China Middle-Long Term (2020, 2030) Energy Development Strategic Research: Energy saving \& Coal [M], Beijing China middle-long term energy development research team. China: Science Press; 2011 [in Chinese].

[3] Statistical Department of National Energy Agency. China energy statistical yearbook [M]. China: China Statistic Press; 2013.

[4] Wang JH, Liu JH, Shang YZ, Jiang D, Xiao WH. China's campaign to create artificial water surfaces in drought-affected regions must consider prevention measures for ecological problems [J]. Environ Earth Sci 2015;74(6):5457-62.

[5] Gu A, Teng F, Wang Y. China energy-water nexus: assessing the water-saving synergy effects of energy-saving policies during the eleventh five-year plan [J]. Energy Convers Manage 2014;85:630-7.

[6] World Energy Council. Water for energy [R], London. United Kingdom: World Energy Council; 2010.

[7] Pan LY, Liu P, Ma LW, Li Z. A supply chain based assessment of water issues in the coal industry in China [J]. Energy Policy 2012;48:93-102.

[8] China Investment Consulting. 2014-2018 analysis and investment consulting report on china coal industry [R], Guangdong. China: CI Consulting; 2012.

[9] Liu X. Lin X. An examination of China's bulk energy transport decisions: coal lumps or electrons? [J]. Adv Transp Stud 2014;3:73-84.

[10] Mou DG, Li Z. A spatial analysis of China's coal flow [J]. Energy Policy 2012;48: $358-68$.

[11] Zhao Y, Wang SX, Duan L, Lei Y, Cao PF, Hao JM. Primary air pollutant emissions of coal-fired power plants in China: current status and future prediction [J]. Renew Sustain Energy Rev 2008;42(36):8442-52.

[12] Wang SX, Hao JM. Air quality management in China: issues, challenges, and options [J]. J Environ Sci 2012;24(1):2-13.

[13] National Energy Administration. 12th five year energy development plan[M] China: Department of State; 2013.

[14] National Bureau of Statistics of the People's Republic of China. 2013 China statistical yearbook [M], Beijing. China: China Statistics Press; 2013. 
[15] Liu CM, Zhao YQ. Possibility of the zero growth of water requirement in China [J]. Bull Chin Acad Sci 2012;26(1):13-6.

[16] Wang JH, Shang YZ, Wang H, Zhao Y, Yin Y. Beijing's water resources: challenges and solutions [J]. J Am Water Resour As 2015;51(3):614-23.

[17] Sun G, Michelsen AM, Sheng ZP, Fang AF, Shang YZ, Zhang HL. Featured collection introduction: water for megacities-Challenges and solutions [J]. J Am Water Resour As 2015;51(3):585-8.

[18] Li PL, Chen GJ, Zhang J. Society of China analysis and forecast (2015) [M] Beijing. China: Social Sciences Academic Press; 2015.

[19] Water resources and hydropower planning and design general institute of MWR. Comprehensive national water resources planning [R]. China: Department of State; 2010 [in Chinese].

[20] Zuo QT, Jin RF, Ma JX, Cui GT. China pursues a strict water resources management system [J]. Environ Earth Sci 2014;72:2219-22.

[21] Lin BQ, Liu JH. Estimating coal production peak and trends of coal imports in China [J]. Energy Policy 2010:38(1):512-9.

[22] State Key Laboratory of Simulation and Regulation of Water Cycle in Rive Basin. The impact of water resource constraints on energy development and utilization [R] China Institute of water resources and hydropower research. China: National Energy Administration; 2014 [in Chinese].
[23] State Grid Research Institute. Subtopic of research for formulating the 13th five state grid development plan: potential development scale and outwards power transmission capacity for major coal power bases [R]. State Grid, China. 2015 [in Chinese].

[24] Ministry of Industry and Information Technology of the People's Republic of China. Ministry of water resources of the People's Republic of China, national bureau of statistics of the People's Republic of China, office of national water saving. Guide for water use efficiency in key industrial sectors [M]. China: Department of State; 2013 [in Chinese].

[25] Liang XY, Wang ZH, Zhou ZJ, Huang ZY, Zhou JH, Cen KF. Up-to-date life cycle assessment and comparison study of clean coal power generation technologies in China [J]. J Clean Prod 2013;39:24-31.

[26] Khan SB, Hanjra MA, Mu JX. Water management and crop production for food security in China: a review [J]. Agr Water Manage 2009;96: 349-60.

[27] Shang YZ, Zhao Y, Shi HW, Wang LT, Wang JH. Analysis of water use trend and its impact factors in Tianjing: south to north water transfers. Water Sci Technol 2015;13(1):33-8 [in Chinese]. 